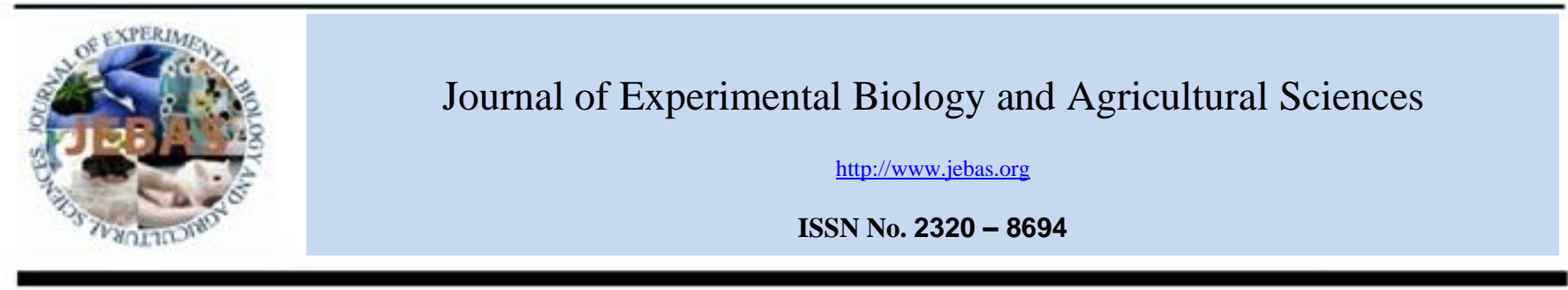

\title{
Lantana camara: AN ALIEN WEED, ITS IMPACT ON ANIMAL HEALTH AND STRATEGIES TO CONTROL
}

\author{
Rakesh Kumar ${ }^{*}$, Rahul Katiyar, Surender Kumar, Tarun Kumar and Vijay Singh
}

ICAR-IVRI, Izatnagar, Bareilly, U.P, India - 243122

Received - April 28, 2016; Revision - April 09, 2016; Accepted - May 21, 2016

Available Online - May 25, 2016

DOI: http://dx.doi.org/10.18006/2016.4(3S).321.337

\begin{abstract}
KEYWORDS
Lantana camara

Lantadenes

Allelopathy

Hepatotoxic

Poisonous

ABSTRACT

Lantana camara is one of the most commonly known noxious weed distributed worldwide. The red flower variety (L. camara var. aculeata) of this weed is mainly toxic and usually prevalent in tropical and sub-tropical countries. Lantana leads to hepatotoxicity, photosensitization and intrahepatic cholestasis almost in all the animals. LA is the main toxic pentacyclic triterpenoid present in this weed. Lantadene toxicity leads to fatty degeneration, bile duct hyperplasia, gall bladder edema, degeneration of parenchymal cells and portal fibrosis observed on histopathological examination. L. camara toxicity causes fluctuation in hematological as well as in biochemical parameters. The management of toxic effects can be achieved by activated charcoal, vaccination and supportive therapy but are not much effective. Besides the harmful effects of this plant, there are some beneficial effects also including antiinflammatory, hepatoprotective action, antitumor action etc. The control of this weed is difficult because of its allelopathic action. Nowadays this plant is used in many recent advanced techniques like phytoremediation of particulate pollution, phytoextraction of heavy metals and many others. Thereby the use of this plant in the field of research can be an effective way to manage this alien weed. As far as the toxicity is concerned it can be prevented by the using conventional therapeutic methods along with immunological, nanotechnological and biotechnological approaches. The aim of this article is to discuss the information regarding its progression, mechanism by which it affect animals, pathological alterations, treatment and what strategies we can opt to get rid of this weed.
\end{abstract}

* Corresponding author

E-mail: rakudoc@gmail.com (Rakesh Kumar)

Peer review under responsibility of Journal of Experimental Biology and Agricultural Sciences.

Production and Hosting by Horizon Publisher India [HPI] (http://www.horizonpublisherindia.in/).

All rights reserved.
All the article published by Journal of Experimental Biology and Agricultural Sciences is licensed under a Creative Commons Attribution-NonCommercial 4.0 International License Based on a work at www.jebas.org.

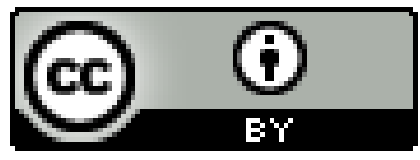




\section{Introduction}

Toxic plants are of major concern to veterinarians because of their harmful effects to livestock in terms of causing mortality and reduction in productivity (Sharma et al., 2007; Diaz, 2011). The severity of toxic effects caused by poisonous plants varies among species and depends upon the nature, part and amount of toxic component taken, environmental conditions, species, age, size and body condition of the animals (Sharma et al., 2007). Along with the toxic effects to livestock, these invasive species are supposed to be the one of the major threat to biodiversity and ecosystem after habitat destruction (Drake et al., 1989; Holmes, 1990; Buckley \& Roughgarden, 2004; De Milliano et al., 2010; Osunkoya \& Perrett, 2011; Zhang \& Chen, 2011). These invasive plants have turned to predators and are responsible for causing diseases in animals as well as in plants (Ehrenfeld, 2006; Chambers et al., 2007; Drenovsky et al., 2012).

Among poisonous plants $L$. camara is one of the most commonly known noxious (Pereira et al., 2003; Mello et al., 2005) and invasive weed worldwide (Palmer et al., 2000; Baars et al., 2003; Totland et al., 2005; Moura et al., 2009; Van Driesche et al., 2010). This weed is responsible to cause heavy mortality of livestock as well as responsible to cause loss of agro and forest ecosystem (Day et al., 2003; Mello et al., 2005; Sharma et al., 2007). L. camara Linn. was introduced as an ornamental shrub by a British in Calcutta Botanical Garden in year 1809, belongs to family Verbenaceae (Bouda et al., 2001; Kumar, 2001; Yadav \& Tripathi, 2003; Munsif et al., 2007). The word Lantana is derived from a Latin word lento, which means "to bend" (Ghisalberti, 2000). This weed is locally known as bunch berry, baraphulnoo, red or wild sage (Sharma et al., 2007). This plant shows change in inflorescence with age and season that's why very difficult to classify taxonomically (Munir, 1996). The binomial name of this plant was given by Linnaeus in year 1753 (Kumarasamyraja et al., 2012). The main varieties of Lantana on the basis of flower colour includes Pink L. camara, White L. camara, Red L. camara, Pink edged red $L$. camara and Orange $L$. camara. Other important species of the genus lantana includes $L$. indica, $L$. crenulata, $L$. trifolia, L. lilacina, $L$. involuerata and $L$. Sellowiance but red flower variety ( $L$. camara var. aculeate) is most toxic (Sharma et al., 2007). A pink variety of Lantana camara called as Taxon is usually grazed by animals in New Zealand and it is nontoxic (Black \& Carter, 1985).

This plant attains a height of 2-3 m and the branches carry curved prickles. The leaves are oval, cuneate, rounded at the base and rugose and crenate at the upper portion, which are rough at maturity and give an offensive odor (Sharma et al., 2007). The fruits are greenish in early stages and become dark blue later on. The green immature fruits are poisonous, while the ripened dark blue fruits are tasty so often taken by birds as well as human beings (Sharma et al., 2007). Many species of lantana are native to Africa and America and has covered many of the neighboring countries (Day et al., 2003). But later on this species has displaced the invertebrate population and other native populations in Africa (Samways et al., 1996). Lantana camara is among 100 most notorious weeds in the world and got entry approximately in 60 countries (GISD, 2010; Lüi, 2011). This weed has been found as a major weed in 12 countries and listed among the 5 most noxious weeds prevalent in Australia and has covered $60 \%$ pastures in Queensland (Holm et al., 1979; Anderson et al., 1983; Ghisalberti, 2000). This weed has replaced Quercus leucotrichphora and Pinus roxburghii forests in Kumaun hills (U.P.) (Bhatt et al., 1994); invaded the teak plantations in Tamil Nadu (Clarson \& Sudha, 1997); covered Western Ghats (South India) (Muniappan \& Viraktamath, 1993) and heart water region of Garhwal (U.P.) (Rajwar, 1998). In Himachal Pradesh, heavy outbreaks of lantana toxicity have been reported from Rampur Bushair and sporadic cases of toxicity have also been reported from cattle, buffaloes and small ruminants (Sharma, 1984).

In general for the success and impact of any weed many biotic and abiotic environmental factors are responsible (Sheppard et al., 2012). One of the most important factor for the huge prevalence of this weed throughout world is its phytotoxic or allelopathic action which is due to the presence of phenolic compounds (umbelliferone, methylcoumarin, salicylic acid etc.) and lantadenes i.e. LA (lantadene A) and LB (lantadene B) (Achhireddy et al., 1984; Jain et al., 1989; Singh et al., 1989; Ferguson \& Rathinasabapathi, 2003). The suppressive allelopathic action of this plant has been seen on certain plant species like Glycine max (Linn), Cyclosorus dentatus Forsk, Triticum aestivum L., Zea mays L. and Lolium multiflorum Lam (Achhireddy et al., 1985; Sharma et al., 2007). This weed is mainly disseminated by droppings of moving animal flocks/ birds, cutting and pollination (Ghazoul 2002; Sharma et al., 2007).

\section{Toxic components of Lantana camara}

The most important toxic components present in this weed are lantadenes. Lantadenes are pentacyclic triterpenes (Table. 1) and often led to hepatotoxicity, photosensitization and jaundice (Sharma et al., 1979; Sharma \& Makkar, 1981; Sharma et al., 2007). There are 2 forms isolated from lantana toxin i.e. crystalline and amorphous. The amorphous form is found to be icterogenic to guinea pigs (Sharma et al., 1988a). Among the known compounds present in lantana, LA is the most hepatotoxic component while certain other compounds like naphthoquinones, oil constituents (citral), iridoid glycosides (Theveside) and some of the oligosaccharides are of lesser importance as far as toxicity is concerned (Ajugose) (Dominguez et al., 1983; Abeygunawardena et al., 1991). The lantadenes are mainly present in the leaves of this plant (Sharma et al., 2007) having varying toxic effects among different species and strains of mammals/livestock. The toxic effects of this plant are evident both in ruminants as well as in non-ruminants (Sharma et al., 2007). 
Table 1 Chemical compounds obtained from Lantana camara and their mechanism of actions.

\begin{tabular}{|c|c|c|}
\hline S.No. Action & Triterpenoids & References \\
\hline 1. Hepatotoxic & LA, LB, LC, RLA and icterogenin & $\begin{array}{l}\text { Brown et al., 1963; Johns et al., 1983a; Sharma et al } \\
\text { 1991; Verma et al., 1997; Wachter et al., 2001; Khan } \\
\text { et al., 2003; Srivastava et al., 2005; Kong et al., 2006; } \\
\text { Parimoo et al., } 2015\end{array}$ \\
\hline $\begin{array}{l}\text { 2. Antimicrobial and } \\
\text { antibacterial activity }\end{array}$ & $\begin{array}{l}\text { LA, LB, oleanolic acid, ursolic acid, 4- } \\
\text { Epihederagonic acid and 24-Hydroxy-3-oxours- } \\
\text { 12-en-28-oic acid }\end{array}$ & $\begin{array}{l}\text { Brown et al., 1963; Sharma et al 1991; Inada et al., } \\
\text { 1995, 1997; Verma et al., 1997; Wachter et al., 2001; } \\
\text { Kong et al., 2006; Kumar et al., 2006; Barreto et al., } \\
\text { 2010; Hussain et al., 2011; Sousa \& Costa, } 2012\end{array}$ \\
\hline $\begin{array}{l}\text { 3. Protein kinase } \mathrm{C} \\
\text { inhibitor }\end{array}$ & Verbascoside & Herbert et al., 1991 \\
\hline 4. Anti-inflammatory & Oleanolic acid, ursolic acid and Oleanonic acid & $\begin{array}{l}\text { Hart et al., 1976b; Johns et al., 1983b; Liu, 1995; } \\
\text { Verma et al., 1997; } \\
\text { Giner-Larza et al., 2001; Benites et al., 2009; Ghosh et } \\
\text { al., 2010; Hussain et al., 2011; Sousa \& Costa, } 2012\end{array}$ \\
\hline 5. Antitumor & $\begin{array}{l}\text { LA, oleanolic acid, ursolic acid, Camaraside and } \\
\text { Lantalucratins A-F }\end{array}$ & $\begin{array}{l}\text { Brown \& Rimington, 1964; Seawright \& Hardlicka, } \\
\text { 1977; Mahato et al., 1994; Deena \& Thoppil, 2000; } \\
\text { Ghisalberti, 2000; Hayashi et al., 2004; Gomes de } \\
\text { Melo et al., 2010; Bisi-Johnson et al., 2011 }\end{array}$ \\
\hline $\begin{array}{l}\text { 6. Anxiolytic action } \\
\text { (Psychiatric disorder) }\end{array}$ & UASG & $\begin{array}{l}\text { Kessler et al., 1994; Awad et al., 2009; Kazmi et al., } \\
2013\end{array}$ \\
\hline 7. Antitubercular & LA & $\begin{array}{l}\text { Seawright \& Hardlicka, 1977; Verma et al., 1997; } \\
\text { Wachter et al., 2001; Kong et al., } 2006\end{array}$ \\
\hline 8. Allelopathy & $\begin{array}{l}\text { LA, Umbelliferone, Hydroxycoumarin, 6- } \\
\text { methylcoumarin, Salicylic acid, gentisic acid, } \\
\text { Vanillic acid and Quercetin }\end{array}$ & $\begin{array}{l}\text { Brown et al., 1963; Johns et al., 1983a; Singh et al., } \\
\text { 1989; Sharma et al 1991; Verma et al., 1997; Wachter } \\
\text { et al., 2001; Kong et al., 2006; Verdeguer et al., } 2009\end{array}$ \\
\hline 9. Antiviral & $\begin{array}{l}\text { LA, LB, LC, RLA, RLB and 22beta-Hydroxy-3- } \\
\text { oxolean-12-en-28-oic acid }\end{array}$ & Johns et al., 1983a; Inada et al., 1995 \\
\hline 1( Hepatoprotective & Oleanolic acid and ursolic acid & $\begin{array}{l}\text { Hart et al., 1976b; Johns et al., 1983b; Singh et al., } \\
\text { 1990, 1991; Liu, 1995; Siddiqui et al., } 1995\end{array}$ \\
\hline 1. Leukotriene inhibitor & Oleanonic acid & $\begin{array}{l}\text { Hart et al., 1976b; Johns et al., 1983b; Giner-Larza et } \\
\text { al., } 2001\end{array}$ \\
\hline 1.. Anti-hyperlipidemic & Oleanolic acid and ursolic acid & $\begin{array}{l}\text { Hart et al., 1976b; Liu, 1995, Liu, 2005; Mishra et al., } \\
\text { 1997; Verma et al., 1997; Chen et al., 2005, Chen et } \\
\text { al., } 2006\end{array}$ \\
\hline 1: Antimutagenic & 22beta-Dimethylacryloyloxylantanolic acid & Barre et al., 1997; Mello et al., 2005 \\
\hline 1< Nematicidal & Camarinic acid, Linaroside and Lantanoside & Siddiqui et al., 1995; Begum et al., 2000 \\
\hline 1: Antiprotozoal & Triterpnes from Lantana montevidensis & Mohameda et al., 2016 \\
\hline 1( Antithrombin & $\begin{array}{l}\text { 5,5-Trans-fused cyclic lactone containing euphane } \\
\text { triterpenoids }\end{array}$ & O’Neill et al., 1998; Weir et al., 1998 \\
\hline 1: Antiproliferative & $\begin{array}{l}\text { Apigenin, Cirsilineol, Eupafolin, Eupatorin and } \\
\text { Hispidulin }\end{array}$ & Nagao et al., 2002 \\
\hline 1) Cardio active & Martynoside & Syah et al., 1998 \\
\hline 1) Insecticidal action & Bioactive molecules without any cross resistance & $\begin{array}{l}\text { Seyoum et al., 2002; Dua et al., 2010; Rajashekar et } \\
\text { al., } 2012 \text { a; Rajashekar et al., } 2012 \text { b; Rajashekar et al., } \\
2012 \text { c }\end{array}$ \\
\hline $2($ Anti-diabetic & UASG & Venkatachalam et al., 2011; Kazmi et al., 2013 \\
\hline $\begin{array}{l}\text { 2. Inhibitor of larval } \\
\text { hatch and exsheathing }\end{array}$ & $\begin{array}{l}\text { Lantana decoction in combination with } A . \\
\text { zerumbet, } M \text {. villosa and } T \text {. minuta }\end{array}$ & Macedo et al., 2012 \\
\hline
\end{tabular}

Abbreviations: Lantadene A (LA), Lantadene B (LB), Lantadene C (LC), Reduced Lantadene A (RLA), Reduced Lantadene B (RLB), Ursolic acid stearoyl glucoside (UASG) 
Among ruminants cattle, buffalo and sheep are highly susceptible, while goats are little resistant to lantadene toxicity (Lal \& Kalra, 1960; Sharma et al., 1988b; Sharma et al., 2007). Guinea pigs show most typical signs of lantana toxicity (Sharma et al., 1988b), while male rats are often resistant to lantana toxicity because of the action of testosterones (Pass et al., 1979a; Pass et al., 1985; Sharma et al., 1992; Sharma et al., 2007). The toxic effects of lantana have been seen in Kangaroos and Ostriches also (Johnson \& Jensen, 1998; Cooper, 2007). Green fodder scarcity is the major causes of lantana toxicity in animals, mainly in those who are often send to pastures without feeding any prior feed (Sharma \& Makkar,
1981). In spite of having many toxic effects this weed is also having anticancer (Gomes et al., 2010; Sathish et al., 2011), antibacterial (Rwangabo et al., 1988; Barreto et al., 2010), antifungal (Sharma et al., 2007), anti-diabetic (Garg et al., 1997), anti-inflammatory, analgesic, antimotility (Ghosh et al., 2010), anti-feedant, larvae repellent (Moffitt et al., 2010), anticonvulsant (Bisi-Johnson et al., 2011), antiulcer and antioxidant actions (Sathish et al., 2011). Oleanolic acid and ursolic acid are the major components, while LA and LB are the minor constituents obtained from Townsville prickly orange variety of lantana (Hart et al., 1976a).

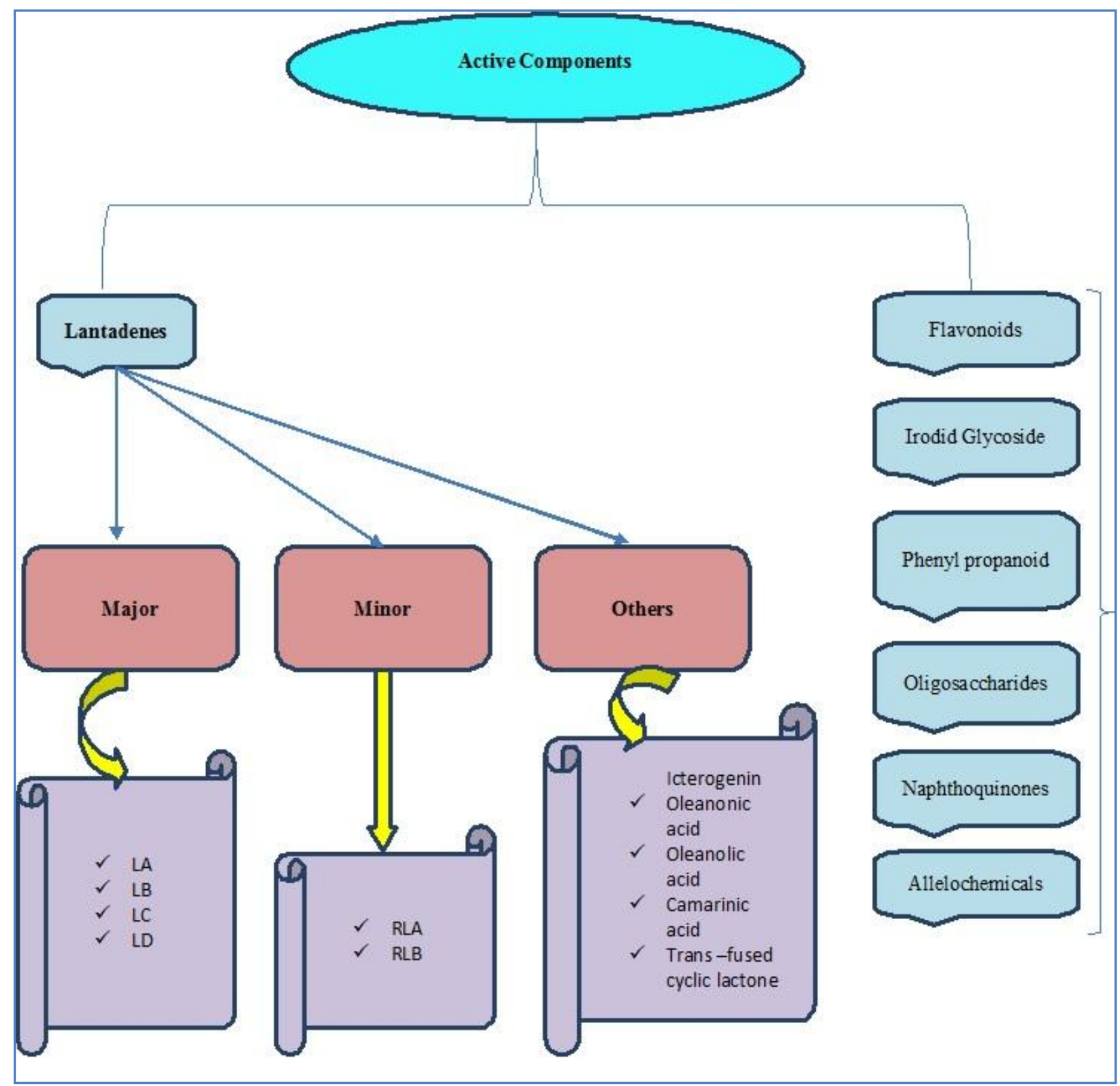

Figure 1 Flow diagram showing different chemical compounds present in Lantana camara. 


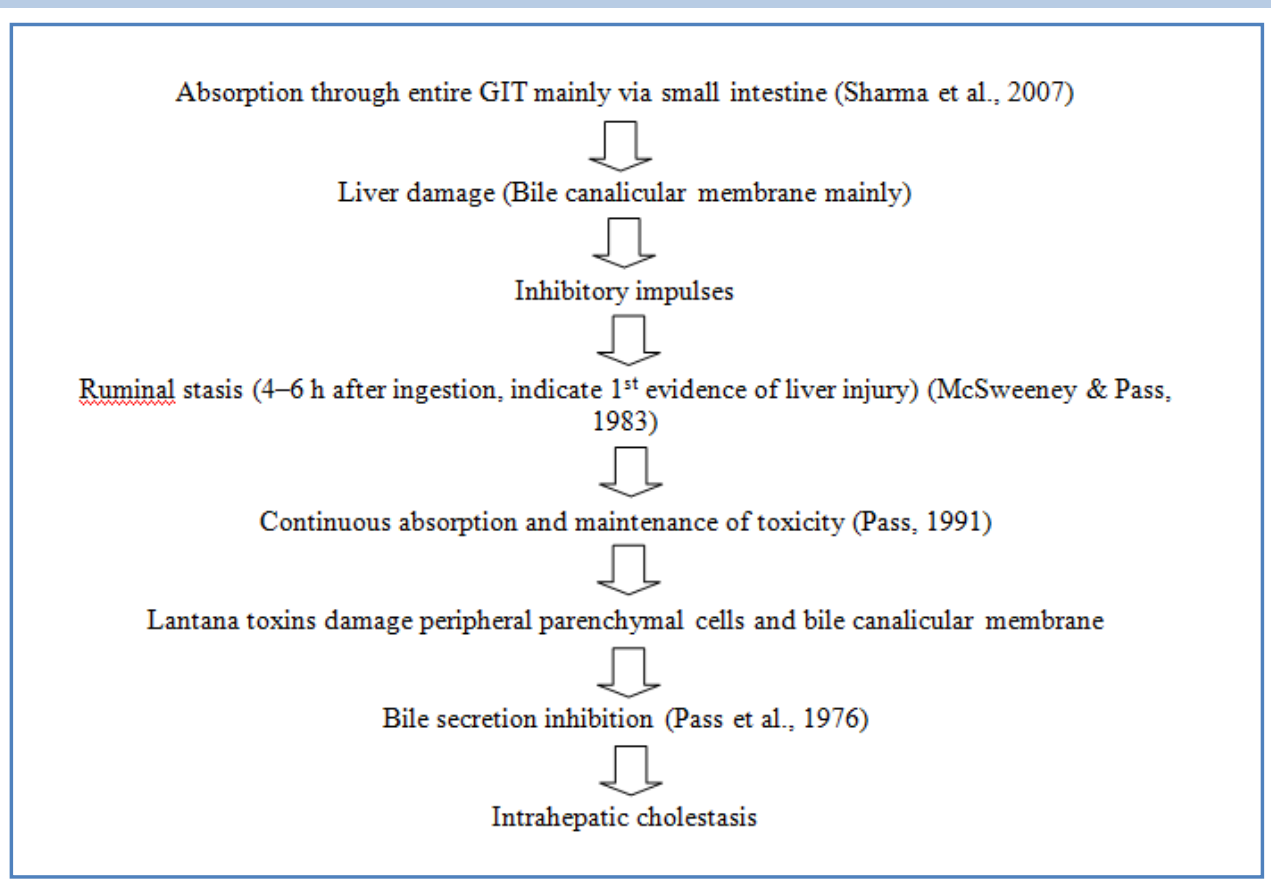

Figure 2 Flow chart of absorption and mechanism of action of lantadenes.

\section{Absorption and mechanism of action of lantadenes}

This toxin has been found to be absorbed through entire GIT (gastrointestinal tract), mainly small intestine (Sharma et al., 2007). The retention time of lantadenes in GIT plays a significant role in progression of effect (Pass et al., 1981a). Bile has not been found to be having any role in toxin absorption.

L. camara mainly attacks liver and kidneys of ruminants and leads to photosensitization. The animals are died within 2-4 days in acute cases. In sub acute lantadene toxicity study a dose dependent mortality was reported (Parimoo et al., 2015). Sluggishness, weakness, bloody diarrhea, edematous ears and eyelids, cracks and fissurs on muzzle and other non-hairy parts, conjunctivitis, ulceration of the tip and under surface of the tongue (if un-pigmented), pale conjunctival, vulvar or vaginal mucous membranes and sclera of eye are some of the clinical signs observed in lantana toxicity. The acute lantana toxicity can be induced either by the leaf powder or by partially purified lantadene powder (Sharma \& Makkar, 1981). In sheep, the oral administration of lantadene leaf powder (at the dose of 4 and $8 \mathrm{~g} / \mathrm{kg}$ body weight) leads to photosensitization, conjunctivitis and bile stained liver while administration of lantadene leaf powder in goats diarrhoea, anorexia and jaundice is evident, but no photosensitization has been seen (Obwolo et al., 1990). The $\mathrm{LD}_{50}$ value of lantadene in sheep is $1-3 \mathrm{mg} / \mathrm{kg}$ body weight, when administered by intravenous route, while the $\mathrm{LD}_{50}$ value is $60 \mathrm{mg} / \mathrm{kg}$ body weight when administered by oral route, because of show absorption (Nellis, 1997). The oral administration of lantadenes at the dose rate of
$25 \mathrm{mg} / \mathrm{kg}$ body weight did not lead to mortality in guinea pigs, but produced hepatotoxic and nephrotoxic effects which were evident on histopathology and on biochemical estimation and were indicative of sub-acute toxicity (Parimoo et al., 2015). Transfer of lantana toxins to milk, placenta, or to the offspring has not been reported, but some teratological effects has been seen in rats (Mello et al., 2005; Sharma et al., 2007). Lantadenes are also having effect on reproductive system, as found to interfere with the sperm count, daily sperm production, and sperm morphology (Sharma et al., 2007).

\section{Hepatotoxic action of lantadenes}

Lantana toxins cause intrahepatic cholestasis along with the inhibition of bile secretions without widespread hepatic necrosis (Pass et al., 1979b). Hepatocellular damage precedes the intense and prolonged jaundice observed during lantana poisoning (Sharma et al., 2007). Significantly, in lantana toxicity, the cells located around the central vein remain normal, while parenchymal cells lying to the periphery of the liver are damaged. Generally, changes associated with intrahepatic cholestasis include dilation of bile canaliculi, loss of microvilli, alterations in enzyme activities and composition of the canalicular membrane (Trauner et al., 1998). Phylloerythrin, a degradation product of chlorophyll formed by the action of microorganisms in the GIT gets accumulated in the liver and leads to photosensitization (Rimington \& Quin, 1934). This type of photosensitization is also called as hepatogenous photosensitization, which occurs due to the impaired hepatobiliary excretion (Kellerman \& Coetzer, 1985). This impaired hepatobiliary excretion of phylloerythrin leads 
to its accumulation in plasma. The inhibition of bile secretion leads to accumulation of bilirubin and ultimately leads to jaundice (Trauner et al., 1998). L. camara toxicity leads to collagen fibres formation in advanced stages, which extends into periportal areas of the liver and can be seen when stained with Foot's reticulin and Van Gieson stain (Gopinath \& Ford, 1969).

5 Clinical signs (de Mello et al., 2003; Sharma et al., 2007)

The dose of lantadenes determines the severity of ictericity (Gopinath \& Ford, 1969). The clinical signs follow a definite pattern as given below:

I. Loss of appetite and decrease in ruminal motility (within $24 \mathrm{~h}$ )

II. Photosensitization in un-pigmented areas leads to necrosis later on (within 24-48h)

III. Icterus (yellowish sclera and other mucus membranes, within 48-72h)

IV. In acute/ more severe cases (death within 2 to 4 days)

V. In less severe cases (death within 1-3 weeks)

VI. In female rats, fetal abnormalities, embryo toxicity and implantation losses have been reported

\section{Pathology}

Seawright (1965) was the first to study the effects of oral administration of lantana leaf extracts on guinea pigs and observed pathological lesions in heart, lungs, liver, gall bladder and kidneys.

C.
A. Gross pathology:

I. Liver: Swollen, fragile, pale yellow, mottled with rounded edges (Sharma et al., 1991, 1992).

II. Gall bladder: 3-4 times distended with dark opaque and viscous contents (Sharma et al., 2007).

III. Kidneys: Swollen, pale and yellowish brown (Seawright \& Allen, 1972).

IV. Stomach: Gas accumulation (Sharma et al., 1991; Sharma et al., 1992).

V. Mucus membranes: Pale (Sharma et al., 1991, 1992).

B. On histopathological examination lantadenes showed degeneration of the periportal parenchymal cells, distended bile canaliculi, fatty degeneration, portal fibrosis, hyperplasia of bile ducts, and edema of gall bladder walls in cattle (Dwivedi et al., 1971; Uppal \& Paul, 1978). Hematological examination in cattle reveals, increase in blood clotting time and hematocrit values but decrease in erythrocyte sedimentation rate has been reported (Hussain \& Roychoudhury, 1992). There was an increase in direct and total bilirubin, increase in the phylloerythrin levels, increase in serum AST, ALP, GLDH, serum total protein, serum albumin, and serum globulin and decrease in albumin/globulin ratio in cattle (Dwivedi et al., 1971; Seawright \& Hrdlicka, 1977). The fibrous tissue formation is seen in chronic liver conditions irrespective of etiology, as in chronic diseases the myofibroblasts produce type 1 collagen which leads to fibrosis.

Table. 2 Histopathological alterations in different animal species.

\begin{tabular}{|c|c|c|c|}
\hline S. No & Species & Histopathological alterations & References \\
\hline 1 & Cattle & $\begin{array}{l}\text { Degeneration of the periportal parenchymal cells, distended bile canaliculi, fatty } \\
\text { degeneration, portal fibrosis, hyperplasia of bile ducts, edema of gall bladder in } \\
\text { cattle. }\end{array}$ & $\begin{array}{l}\text { Dwivedi et al., } \\
\text { 1971; Uppal \& } \\
\text { Paul, } 1978\end{array}$ \\
\hline 2 & Goats & $\begin{array}{l}\text { Hemorrhages of inter-sinusoidal spaces, coagulative necrosis, cirrhosis and } \\
\text { proliferation of bile ductules, fatty degeneration of proximal convoluted tubules } \\
\text { of kidneys, proliferation of bile ductules in the liver occurs. }\end{array}$ & $\begin{array}{l}\text { Sharma et al., } \\
2007\end{array}$ \\
\hline 3 & Sheep & Centrilobular cells vacuolation with bile mainly in chronic cases. & $\begin{array}{l}\text { Sharma et al., } \\
2007\end{array}$ \\
\hline 4 & $\begin{array}{l}\text { Guinea Pigs } \\
\text { and Rats }\end{array}$ & $\begin{array}{l}\text { Periportal vacoular degeneration, fatty degeneration, haemorrhages, bile duct } \\
\text { proliferation with yellow-brown bile plugs, portal fibrosis in liver. Fatty } \\
\text { degeneration of PCT, vacuolar degeneration of tubular epithelium of cortex, } \\
\text { hyaline cast in kidneys. Oedema and haemorrhagic ulcer in gall bladder. } \\
\text { Subepicardial petechial haemorrhages in heart along with pulmonary oedema and } \\
\text { haemorrhages in lung. }\end{array}$ & $\begin{array}{l}\text { Sharma et al., } \\
\text { 1992; Parimoo et } \\
\text { al., } 2015\end{array}$ \\
\hline 5 & Rabbits & $\begin{array}{l}\text { Portal fibrosis, bile canaliculi dilatation, degeneration and swelling of hepatic } \\
\text { cells, biliary hyperplasia, biliary cirrhosis in the liver. Tubular nephrosis, } \\
\text { inflammatory interstitial reaction, degeneration of tubules in the kidneys. }\end{array}$ & $\begin{array}{l}\text { Sharma et al., } \\
2007\end{array}$ \\
\hline
\end{tabular}


Table. 3 Hematological examination in different animal species.

\begin{tabular}{|c|c|c|c|}
\hline S. No. & Species & Hematological parameters & References \\
\hline 1. & Cattle & $\begin{array}{l}\text { Increase in blood clotting time and hematocrit values but decrease in } \\
\text { erythrocyte sedimentation rate. }\end{array}$ & $\begin{array}{l}\text { Hussain \& } \\
\text { Roychoudhury, } 1992\end{array}$ \\
\hline 2. & Sheep & $\begin{array}{l}\text { Transient increase in the hematocrit value and neutrophils number but a } \\
\text { decline in number of thrombocytes seen. }\end{array}$ & Seawright, 1963 \\
\hline 3. & Goat & $\begin{array}{l}\text { Progressive decrease in packed cell volume, hemoglobin, and total erythrocyte } \\
\text { count while increase in leukocyte count and blood clotting time observed. }\end{array}$ & Ali et al., 1995 \\
\hline 4. & $\begin{array}{l}\text { Guinea } \\
\text { pigs }\end{array}$ & $\begin{array}{l}\text { Increase in hematocrit, erythrocyte and leukocyte number, hemoglobin and } \\
\text { urea levels in acute lantana toxicity. Significant increase in PCV and TLC, but } \\
\text { not in TEC observed in sub-acute lantadene toxicity study. }\end{array}$ & $\begin{array}{l}\text { Sharma et al., 2007; } \\
\text { Parimoo \& Sharma, } \\
2014\end{array}$ \\
\hline
\end{tabular}

Table. 4 Biochemical Alterations in different animal species.

\begin{tabular}{|c|c|c|c|}
\hline S. No. & Species & Biochemical Alteration & References \\
\hline 1. & Cattle & $\begin{array}{l}\text { Increase in direct and total bilirubin, increase in the phylloerythrin levels, } \\
\text { increase in serum AST, ALP, GLDH, serum total protein, serum albumin, and } \\
\text { serum globulin and decrease in albumin/globulin ratio. }\end{array}$ & $\begin{array}{l}\text { Dwivedi et al., 1971; } \\
\text { Seawright \& Hrdlicka, } \\
1977\end{array}$ \\
\hline 2. & Sheep & No change in the serum ALP, AST and ALT levels. & $\begin{array}{l}\text { Seawright, } 1963 \text {; } \\
\text { Dwivedi et al., } 1971\end{array}$ \\
\hline 3. & Goats & Rise of serum bilirubin, AST, creatinine, GGT and BUN levels. & Obwolo et al., 1991 \\
\hline 4. & $\begin{array}{l}\text { Guinea } \\
\text { pigs }\end{array}$ & $\begin{array}{l}\text { Marked increase in conjugated form of bilirubin, AST, LDH, GLDH, BUN, } \\
\text { ALT and SDH. No significant increase in total proteins, ACP and creatinine } \\
\text { levels were observed in sub-acute toxicity of lantadenes while ALT, AST and } \\
\text { ALP were significantly elevated. }\end{array}$ & $\begin{array}{l}\text { Sharma et al., } 1992 ; \\
\text { Sharma et al., } 2007 \text {; } \\
\text { Parimoo et al., } 2015\end{array}$ \\
\hline
\end{tabular}

\section{Treatment}

Specific treatment for lantana toxicity is still lacking, the preventive measures are more effective than curative measures to decline the harmful effects of this notorious weed (Oyourou et al., 2013), but there are some conventional treatment methods which can be applied (McSweeney \& Pass, 1982; Sharma et al., 2007):

I. Keep the intoxicated animals away from light; provide fluid therapy and adequate feed.

II. Administration of activated charcoal $5 \mathrm{~g} / \mathrm{kg}$ body weight with electrolyte in stomach tube within $24 \mathrm{~h}$, which reduces the absorption of lantadenes.

III. Administration of bentonite $5 \mathrm{~g} / \mathrm{kg}$ body weight. It is much cheaper than charcoal but takes longer time to show desired effect.

IV. Administration of Tefroli powder obtained from Tephrosia purpurea plant.

V. Oral administration of liver tonics like Liv-52.

VI. Vitamin B-complex administration.

VII. Enzymatic removal of bilirubin by bilirubin-oxidase, which is effective in jaundice.

VIII. Herbal tea i.e. Yin Zhi Huang (YZH) from Artemisia capillaries, effective in neonatal jaundice.

IX. Herbal plants like Tinospora cordifolia, Gingko biloba, Berberis lycium and Hippophae salicifolia also show ameliorative effect on $L$. camara-induced toxicity in guinea pigs. Gingko biloba has also shown the protective effect against $\mathrm{CCl}_{4}$ (Shenoy et al., 2001; Chavez- Morales et al., 2011) and rifampicin (Naik \& Panda, 2008) leads to decrease ALT and AST levels when fed to rats. Ginko biloba also shows hepatoprotective action against glyphosate, uranium and $\mathrm{CCl}_{4}$ toxicity, which are potent hepatotoxicant (Yapar et al., 2010; Cavusoglu et al., 2011; Guo et al., 2011).

X. Vaccination can also be done but it is not an effective measure.

XI. Bacterial strains like Pseudomonas picketii, Alcaligenes faecalis and Alcaligenes odorans can be used which degrades the LA.

XII. Rumenotomy can be done to evacuate the entire GI tract.

\section{Prevention}

It is the cost effective way of controlling the accidental introduction of lantana into the ecosystem. The different ways by which lantana infestation can be prevented includes (Priyanka et al., 2013):

i. The international standards for trading partner countries in a well targeted form must be implemented.

ii. The adequate surveillance and monitoring system for early detection of lantana infestation must be implemented.

iii. Implementation of strict border controls, transport controls and quarantine methods should be followed. 
The biosecurity and quarantine system should be strengthened in an organized form.

iv. Collaboration with government agencies, so that outline can be made to prevent the spread of lantana. Involvement of all the agencies concerned with invasive species management is must.

v. Educate and communicate people regarding the harmful effects of this alien weed which can be done by organizing campaigns and training programs.

\section{Control and Management}

Against this alien weed 41 biological agents are introduced worldwide since 1902 which covers the largest and longest running control program for weed control, but no satisfactory success has been achieved till date (Baars \& Neser, 1999; Sheppard, 2003; Zalucki et al., 2007). In past years a huge man power and different ways were used to eradicate lantana. Many mechanical, biological techniques, use of fire etc. were used in India but no success was achieved. In Australia (Haseler, 1979) and South- Africa (Marsh, 1978) efforts were made to eradicate this weed but everything was vain.

\section{Strategies which can be opted for controlling $L$. camara includes}

1. Monitoring of lantana population by mapping, remote sensing, GPS/GNSS techniques and satellite; assessment and implementation of control measures like crop rotation, sowing the pastures, plantation etc. are the key steps to be taken for successful control of this alien weed (Priyanka et al., 2013).

2. The maximum use of this weed in our routine life can decrease the incidences of its prevalence. So, the small scale research projects can be supported to utilize this plant in many different ways like:

i. Train the people for making furniture, baskets, mosquito repellent cakes, incense sticks etc. from lantana. This method is followed in few states of India like Tamil Naidu.

ii. This plant is a part of folk medicines for many ailments like cancers, asthma, respiratory infections etc. (Deena \& Thoppil, 2000; Ghisalberti, 2000; Bevilacqua et al., 2011). In many parts of the world, this weed is used in the treatment of many ailments like wound healing, scratches, rheumatism, fever, toothache, rashes and malaria (Chharba et al., 1993; Ghisalberti, 2000; Silva et al., 2005). Because of its multifarious applications in health, this weed is also called as traditional and tropical folk medicinal plant (Taviano et al., 2007; Awad et al., 2009; Moffitt et al., 2010; Pour \& Sasidhara, 2011).

iii. In India because of human health concerns and environmental hazards the insecticides are never mixed with grains, and biofumigants are often proven as very good model against the insects and have no risk of cross resistance as well (Rajashekar et al., 2012a; Rajashekar et al., 2012b). The extracts obtained from different parts of lantana have many beneficial properties like anthelminthic, antibacterial, anti-ulcerogenic, anti-inflammatory, termiticidal, antifungal, antiprotozonal, antipyretic and many more (Siddiqui et al., 1995; Barre et al., 1997; Kumar et al., 2006; Rajesh \& Suman, 2006; Hussain et al., 2011; Sousa \& Costa, 2012). The leaves of this weed contain many bioactive compounds and also have insecticidal activities (Khan et al., 2002; Dua et al., 2010; Rajashekar et al., 2012c).

iv. Essential oils obtained from $L$. camara leaves have adulticidal activity against mosquitoes (Dua et al., 2010). The essential oils obtained from the leaves and flowers of this weed, also shows fumigant action (Alitonou et al., 2004; Zoubiri \& Baaliouamer, 2012).

v. The leaf extracts of this weed are having inhibitory effect on aquatic weeds like Microcystis aeruginosa and Eichhornia crassipes (Sharma et al., 2007; Rai, 2013) and are often used for controlling pests and almond moths in an environment friendly way (Gotyal et al., 2010; Rajashekar at al., 2012c; Rajashekar et al, 2013).

vi. It also improves the hydraulic properties which is often beneficial to certain crops like wheat and rice (Bhushan \& Sharma, 2005; Rai, 2013).

vii. The fruit eating populations consume dark blue ripened fruits of this plant as a food (Gosper \& Vivian-Smith, 2006; Sharma et al., 2007; Rai, 2013). So it can be used as a source of food.

viii. The methanolic extract of $L$. camara can reduce lipid peroxidation and can elevate the level of glutathione, thereby can prevent free radicals induced damage (Loganayaki \& Manian, 2010; Sathish et al., 2011). L. camara along with $L$. montevidensis shows antioxidant activity (Sousa et al., 2015).

ix. This weed can be used as a bio-fuel and in Kraft pulping (Naithani \& Pande, 2009; Bhatt et al., 2011).

x. Lantana camara nowadays is being utilized for vermicomposting (Hussain et al., 2015).

3. Chemical control includes the use of chemical weapons like Brush killer 64, Gramoxone, Bladex-H etc. which can reduce the spread of lantana.

4. The biological control is supposed to be the cost effective and long term solution to get rid of this alien weed (Hunt et al., 2008). Risk assessment is most effective tool to check the stability of biological control agents used against lantana (Arnett \& Louda, 2002; Baars, 2003; Berner \& Bruckart, 2005; Briese, 2005; Sheppard et al., 2005; Wright et al., 2005; Ding et al., 2006; Hunt et al., 2008). Biological control includes: 
Table. 5. List of some useful products obtained from different parts L. Camara.

\begin{tabular}{|clll|}
\hline S. No. & Part & Compounds & Action \\
\hline 1. & Leaves, stem & Oleanonic acid & Anti-inflammatory \\
\hline 2. & Leaves, stem, roots & Oleanolic acid & Antimicrobial, antitumor, anti-inflammatory \\
\hline 3. & Aerial parts & Camarinic acid, Lantanoside & Nematicidal \\
\hline 4. & Leaves & Lactones containing euphanes & Anti-thrombin \\
& & & \\
\hline $\mathbf{5 .}$ & Leaves & Apigenin & Anti-proliferative \\
\hline $\mathbf{6 .}$ & Leaves & Camaraside & Antitumor \\
\hline 7. & Leaves and branches & Martynoside & Cardioactive \\
\hline
\end{tabular}

(Sources: Sharma et al., 2007; Hussain et al., 2011; Sousa \& Costa, 2012)

i. Use of certain biological agents like plume moth (Lantanophaga spp.), seed fly (Ophiomyia spp.), fungus (Corynespora cassiicola) (Pereira et al., 2003) and Tingid bug (Leptobyrsadecora).

ii. Some of the plants like Aconophora compressa and Citharexylum spinosum can be introduced for the biological control of this weed as in Australia (Palmer et al., 1996; Dhileepan et al., 2006; Manners \& Walter, 2009; Manners et al., 2010).

5. In some of the states like Himachal Pradesh the state forest department has introduced a "Cut Root Stock (CRS) "method for the eradication of this weed.

6. Use of lantana in research can be done e.g. the ripened berries of lantana are often used for preparing silver nanoparticles nowadays (Kumar et al., 2015).

7. In many metal polluted tropical and sub-tropical countries this weed is used in phytoextraction of heavy metals especially lead (Jusselme et al., 2012; Jusselme et al., 2013; Jusselme et al., 2015) and phytoremediation of particulate pollution (Rai, 2012; Rai, 2015a; Rai, 2015b).

\section{Differential diagnoses}

It is little bit difficult to differentially diagnose lantana toxicity from other plant toxicities, because almost similar kind of lesions and symptoms are produced by these plants e.g. Senecia, Crotolaria, Helenium spp (Sneezeweed) produce hepatotoxicity like lantana poisoning. The oak poisoning also produces similar signs. Therefore clinical history, clinical signs, presence of plant in feed and ruminal contents are quite informative to assess the lantana toxicity.

\section{Conclusion}

L. camara is an invasive toxic weed which is dominating globally and is capable of over-run neighbouring young plantations. The allelopathic effect is the major contributor for hampering the growth of surrounding vegetation and flare up wherever it finds place. The lantadenes are the major toxic components present in this plant which are responsible to cause toxicity in almost all the animals thereby leads to economic losses to the farmers by causing diseases and mortality. Specific treatment for lantana toxicity is not available and only preventive measures are supposed to be more effective. Certain methods for the management of toxicity are often used but are not much effective. Besides many harmful effects this weed is having many advantages. But the harmful effects often supervenes the utility of this weed. So, it is very important to develop the measures to control this weed in a desirable and cost effective way. Many approaches are applied to destroy this weed but most of them are not effective. Only the utilization of this plant is supposed to be an effective method for managing this weed. This utilization approach can only be capable to get rid of the negative impact of this weed on environment and can help to promote economic upliftment of rural economy. It is also very important to develop rational therapies against lantana toxicity by using immunological and biotechnological approaches, so that along with utilization the therapeutic measures can be evolved for livestock treatment. Already many pharmacological effects of this weed have been known, but still there is a scope to use this plant in the field of nanotechnology and therapeutics which can provide long term solutions to avoid the cruelty of this weed to the livestock, mankind, vegetation and our ecosystem.

\section{Conflict of interest}

Authors would hereby like to declare that there is no conflict of interests that could possibly arise.

\section{References}

Abeygunawardena C, Kumar V, Marshall DS, Thomson RH, Wickramaratne DBM (1991) Furanonaphthoquinones from two lantana species. Phytochemistry 30: 941-945.

Achhireddy NR, Suigh M, Achhhireddy LL, Nigg HN, Nagy S (1984) Isolation and Partial Characterization of Phytotoxic 
compounds from Lantana (Lantana camara, L). Journal of Chemical Ecology 11: 979-988.

Achhireddy NR, Singh M, Achhireddy LL, Nigg HN, Nagy S (1985) Isolation and partial characterisation of phytotoxic compounds from Lantana (Lantana camara L.). Journal of Chemical Ecology 11: 979-988.

Ali MK, Pramanik AK, Guha C, Misra SK, Basak DK (1995) Gross and histopathological changes in experimental Lantana camara poisoning in goats. Indian Journal of Animal Health 34: $17-18$.

Alitonou G, Avlessi F, Bokossa I, Ahoussi E, Dangou J, Sohounhloue DCK (2004) Composition Chimique et Activite Biologique de l'Huile Essentielle de Lantana camara L.. Compte Rendue de Chimie 7:1101-1105.

Anderson RC, Liberta AE, Dickman LA, Katz AJ (1983) Spatial variation in vesicular-arbuscular mycorrhiza spore density. Bulletin of the Torrey Botanical Club 110: 519-525. DOI: $10.2307 / 2996286$.

Arnett AE, Louda SM (2002) Re-test of Rhinocyllus conicus host specificity, and the prediction of ecological risk in biological control. Biological Conservation 106: 251-257.

Awad R, Muhammad A, Durst T, Trudeau VL (2009) Bioassay guided fractionation of lemon balm (Melissa officinalis L.) using an in vitro measure of GABA transaminase activity. Phytotherapy Research 23: 1075-1081.

Baars JR, Neser S (1999) Past and present initiatives on the biological control of Lantana camara (Verbenaceae) in South Africa. In: Olckers T, Hill MP (Eds.), Biological control of weeds in South Africa (1990-1999). African Entomology, Memoir No. 1. Entomological Society of Southern Africa, Johannesburg, South Africa. pp. 182.

Baars JR (2003) Geographic range, impact, and parasitism of Lepidopteran species associated with the invasive weed Lantana camara in South Africa. Biological Control 28: 293 301.

Baars JR, Urban AJ, Hill MP (2003) Biology, host range, and risk assessment supporting release in Africa of Falconia intermedia (Heteroptera: Miridae), a new biocontrol agent for Lantana camara. Biological Control 28: 282-292.

Barre JT, Bowden BF, Coll JC, DeJesus J, De La Fuente VE, Janairo GC, Ragasa CY (1997) A bioactive triterpene from Lantana camara. Phytochemistry 45:321-324.

Barreto F, Sousa E, Campos A, Costa J, Rodrigues F (2010) Antibacterial activity of Lantana camara Linn and Lantana montevidensis Brig extracts from Cariri-Ceará, Brazil. Journal of Young Pharmacists 2: 42-44.
Begum S, Wahab A, Siddiqui BS, Qamar F (2000) Nematicidal constituents of the aerial parts of Lantana camara. Journal of Natural Products 63: 765-767.

Benites J, Moiteiro C, Miguel G, Rojo L, Lopez J, Venancio F, Ramalho L, Feio S, Dandlen S, Casanova H, Torres I (2009) Composition and biological activity of the essential oil of Peruvian Lantana camara. Journal of the Chilean Chemical Society 54: 379-384.

Berner DK, Bruckart WL (2005) A decision tree for evaluation of exotic plant pathogens for classical biological control of introduced invasive weeds. Biological Control 34 : 222-232.

Bevilacqua AHV, Suffredini IB, Romoff P, Lago JHG, Bernardi MM (2011) Toxicity of apolar and polar Lantana camara L. crude extracts in mice. Research in Veterinary Science 90: 106-115.

Bhatt YD, Rawat YS, Singh SP (1994) Changes in ecosystem functioning after replacement of forest by Lantana shrubland in Kumaon Himalaya. Journal of Vegetation Science 5: 67-70.

Bhatt N, Gupta PK, Naithani S (2011) Ceric-induced grafting of Acrylonitrile onto Alpha Cellulose isolated from Lantana camara. Cellulose Chemistry and Technology 45 : 321-327.

Bhushan L, Sharma PK (2005) Long-term effects of lantana residue additions on water retention and transmission properties of a medium-textured soil under rice-wheat cropping in northwest India. Soil use and management 21: 3237.

Bisi-Johnson MA, Obi CL, Hattori T, Oshima Y, Li S, Kambizi L, Eloff JN, Vasaikar SD (2011) Evaluation of the antibacterial and anticancer activities of some South African medicinal plants. BMC complementary and alternative medicine 11: 14. doi: 10.1186/1472-6882-11-14.

Black H, Carter RG (1985) Lantana poisoning of cattle and sheep in New Zealand. New Zealand Veterinary journal 33: 136-137.

Bouda H, Tapondjou LA, Fontem DA, Gumedzo MYD (2001) Effect of essential oils from leaves of Ageratum conyzoides, Lantana camara and Chromolaena odorata on the mortality of Sitophilus zeamais (Coleoptera, Curculionidae). Journal of Stored Products Research 37: 103-109.

Briese DT (2005) Translating host-specificity test results into the real world: the need to harmonize the yin and yang of current testing procedures. Biological Control 35: 208-214.

Brown JMM, Rimington C, Sawyer BC (1963) Studies on biliary excretion in the rabbit II. The relationship between the chemical structure of certain natural or synthetic pentacyclic triterpenes and their icterogenic activity. P 1. The substituents 
on carbon atoms 3, 17, 22 and 24. Proceedings of Royal Society B 157: 473-491.

Brown JMM, Rimington C (1964) Studies on biliary excretion II. The relationship between the chemical structure of certain natural or synthetic pentacyclic triterpenes and their icterogenic activity. Part 2. The substituents on carbon atoms 17, 19, 20 and 22. Proceedings of Royal Society B 160: 246257.

Buckley LB, Roughgarden J (2004) Biodiversity conservation: effects of changes in climate and land use. Nature 430: 2-20

Cavusoglu K, Yapar K, Oruc E, Yalcin E (2011) Protective effect of Ginkgobiloba L. leaf extract against glyphosate toxicity in Swiss albino mice. Journal of Medicinal Food 14: 1263-1272.

Chambers JC, Roundy BA, Blank RR, Meyer SE, Whittaker A (2007) What makes Great Basin sagebrush ecosystems invasible by Bromus tectorum? Ecological Monographs 77 : 117-145.

Chavez-Morales RM, Jaramillo-Juarez F, Posadas Del Rio FA, Reyes RomeroMA, Rodriguez-Vazquez ML, Martinez-Saldana MC (2011) Protective effect of Ginkgo biloba extract on liver damage by a singledose of $\mathrm{CCl} 4$ in male rats. Human and Experimental Toxicology 30: 209-216.

Chen Y, Liu J, Yang X, Zhao X, Xu H (2005) Oleanolic acid nanosuspensions: preparation, in-vitro characterization and enhanced hepatoprotective effect. Journal of Pharmacy and Pharmacology 57: 259-264.

Chen J, Liu J, Zhang L, Wu G, Hua W, Wu X, Sun H (2006) Pentacyclic triterpenes. Part 3: Synthesis and biological evaluation of oleanolic acid derivatives as novel inhibitors of glycogen phosphorylase. Bioorganic \& Medicinal Chemistry Letters 16: 2915-2919.

Chhabra SC, Mahunnah RLA, Mashiu EN (1993) Plants used in Eastern Tanzania VI Angiosperms (Sapotaceae) to Zingiberaceae). Jornal of Ethnopharmacol 39: 83-103.

Clarson D, Sudha P (1997) Studies on the weeds infestation and their management in teak plantations. Indian Forester 123:740-745.

Cooper RG (2007) Poisoning in ostriches following ingestion of toxic plants-field observations. Tropical Animal Health Production 39: 439-442.

Day M, Wiley CJ, Playford J, Zalucki, MP (2003) Lantana: Current Management, Status and Future Prospects. Australian Centre for International Agricultural Research, Canberra. de Mello FB, Jacobus D, de Carvalho KC, de Mello JR (2003) Effects of Lantana camara (Verbenaceae) on rat fertility. Veterinary and Human Toxicology 45: 20-23.

De Milliano JW, Woolnough A, Reeves A, Shepherd D (2010) Ecologically significant invasive species: A monitoring framework for natural resource management groups in Western Australia. Natural Heritage Trust 2 Program, Department of Agriculture and Food, Western Australia, South Perth, Australia 14.

Deena MJ, Thoppil JE (2000) Antimicrobial activity of the essential oil of Lantana camara. Fitoterapia 71: 453-455.

Dhileepan K, Trevino M, Raghu, S (2006) Temporal patterns in incidence and abundance of Aconophora compressa (Hemiptera: Membracidae), a biological control agent for Lantana camara, on target and non-target plants. Environmental Entomology 35 : 1001-1012.

Diaz GJ (2011) Toxic plants of veterinary and agricultural interest in colombia. International Journal of Poisonous Plant Research 1 : 1-19.

Ding J, Blossey B, Du Y, Zheng F (2006) Galerucella birmanica (Coleoptera: Chrysomelidae), a promising potential biological control agent of water chestnut, Trapa natans. Biological Control 36: 80-90.

Dominguez XA, Franco R, Cano G, Garcia FMC, Dominguez SXA Jr, Pena ML de la (1983) Isolation of a newfurano-1, 4naphthoquinone, diodantunezone from Lantana achyranthifolia. Planta Medica 49: 63. DOI: 10.1055/s-2007969816.

Drake JA, Mooney HA, Di Castri F, Groves F, Kruger FJ, Rejmánek M, Williamson M (1989) Biological Invasions: A Global Perspective. John Wiley and Sons, New York.

Drenovsky RE, Grewell BJ, D'Antonio CM, Funk, JL, James JJ, Molinari N, Parker IM, Richards CL (2012) A functional trait perspective on plant invasion. Annals of Botany. doi: 10.1093/aob/mcs100.

Dua VK, Pandey AC, Dash AP (2010) Adulticidal activity of essential oil of Lantana camara leaves against mosquitoes. Indian Journal of Medical Research 131: 434-439.

Dwivedi SK, Shivnani GA, Joshi HC (1971). Clinical and biochemical studies in lantana poisoning in ruminants. Indian journal of Animal Sciences 41: 948-953.

Ehrenfeld JG (2006) A potential novel source of information for screening and monitoring the impact of exotic plants on ecosystems. Biological Invasions 8: 1511-1521. 
Ferguson JJ, Rathinasabapathi B (2003) Allelopathy: how plants suppress other plants. Document HS944, Horticultural Sciences Department, Florida Cooperative Extension Service, Institute of Food and Agricultural Sciences, University of Florida. July. Web page: edis.ifas.ufl.edu/pdf files/HS/HS18600.pdf.

Garg SK, Shah MAA, Garg KM, Farooqui MM, Sabir M (1997) Antilymphocytic and immunosuppressive effects of Lantana camara leaves in rats. Indian Journal of Experimental Biology 35: 1315-1318.

Ghazoul J (2002) Flowers at the front line of invasion? Ecological Entomology 27: 638-640.

Ghisalberti EL (2000). Lantana camara L. (Verbenaceae). Fitoterapia71: 467-486.

Ghosh S, Das Sarma M, Patra A, Hazra B (2010) Antiinflammatory and anticancer compounds isolated from Ventilago madraspatana Gaertn, Rubia cordifolia Linn. and Lantana camara Linn. Journal Pharmacy and Pharmacology 62: 1158-66.

Giner-Larza EM, Manez S, Recio MC, Giner RM, Prieto JM, Cerda-Nicolas M, Rios JL (2001) Oleanonic acid, a 3oxotriterpene from Pistacia, inhibits leukotriene synthesis and has anti-inflammatory activity. European Journal of Pharmacology 428:137-143.

Global Invasive Species Database-GISD (2010) Species Database.

http://www.issg.org/database/species/search.asp?sts=sss\&st=ss $\mathrm{s} \& \mathrm{fr}=1 \& \mathrm{x}=0 \& \mathrm{y}=0 \& \mathrm{sn}=\& \mathrm{rn}=$ India\&hci=- $\quad$ 1\&ei=$1 \&$ Lang $=\mathrm{EN}$.

Gomes de Melo J, de Sousa Araújo TA, Thijan Nobre de Almeida e Castro V, Lyra de Vasconcelos Cabral D, do Desterro Rodrigues M, Carneiro do Nascimento S, Cavalcanti de Amorim EL, de Albuquerque UP (2010) Antiproliferative activity, antioxidant capacity and tannin content in plants of semi-arid northeastern Brazil. Molecules 15 : 8534-8542.

Gopinath C, Ford EJH (1969) The effect of Lantana camara on the liver of sheep. Jornal of Pathology 99: 75-85.

Gosper CR, Vivian-Smith G (2006) Selecting replacements for invasive plants to support frugivores in highly modified sites: a case study focusing on Lantana camara. Ecological Management and Restoration 7: 197e203.

Gotyal BS, Srivastava C, Walia S, Jain SK, Reddy DS (2010) Efficacy of wild sage (Lantana camara) extracts against almond moth (Cadra cautella) in stored wheat (Triticum aestivum) seeds. Indian Journal of Agriculture Science 80: 433-436.
Guo WY, Ni ZJ, Wang ZX, Fu ZR, Li RD (2011) The protective effectsof Ginkgo leaf extract on CCL4-induced liver injury in mice. Journal of Medicinal Plants Research 5: 23612364.

Hart NK, Lamberton JA, Sioumis AA, Saures H (1976a) New triterpenes of Lantana camara. A comparative study of the constituents of several taxa. Australian Journal of Chemistry 29: 655-671. doi:10.1071/CH9760655.

Hart NK, Lamberton JA, Sioumis AA, Saures H, Seawright AA (1976b) Triterpenes of toxic and nontoxic taxa of Lantana camara. Experientia 32: 412-413.

Haseler WH (1979) Annual Report 1978-79 Sir Alan Fletcher Research Station. Queensland, Department of Lands. Secondary Journal, Biocontrol News and Information 1: 317.

Hayashi KI, Chang FR, Nakanishi Y, Bastow KF, Cragg G, McPhail AT, Nozaki H and Lee KH (2004) Antitumor agents Lantalucratins A-F, new cytotoxic naphthoquinones from Lantana involucrata. Journal of Natural Products 67: 990-993.

Herbert JM, Maffrand JP, Taoubi K, Augereau JM, Fouraste I and Gleye J (1991) Verbascoside isolated from Lantana camara, an inhibitor of protein kinase C. Journal of Natural Products 54: 1595-1600.

Holm LG, Pancho JV, Herberger JP, and Pluncknett DL (1979) A geographical atlas of the world weeds. John Wiley, New York.

Holmes PM (1990) Dispersal and predation in alien Acacia. Oecologia 83: 288-290.

Hunt EJ, Kuhlmann U, Sheppard A, Qin TK, Barratt BIP, Harrison L, Mason PG, Parker D, Goolsby J (2008) Review of invertebrate biological control agent regulation in Australia, New Zealand, Canada and the USA: recommendations for a harmonised European regulatory system. Journal of Applied Entomology 132: 89-123.

Hussain P and Roychoudhury RK (1992) Liver function tests in Lantana camara (Linn.) poisoning in cattle. Indian Journal of Veterinary Medicine 12: 22-33.

Hussain H, Hussain J, Al-Harrasi A, Shinwari ZK (2011) Chemistry of some species genus Lantana. Pakistan Journal of Botany 43: 51-62.

Hussain N, Abbasi T, Abbas SA (2015) Vermicomposting eliminates the toxicity of Lantana (Lantana camara) and turns it into a plant friendly organic fertilizer. Journal of Hazardous Materials 298: 46-57. 
Inada A, Nakanishi T, Tokuda H, Nishino H, Iwashima A and Sharma OP (1995) Inhibitory effects of lantadenes and related triterpenoids on Epstein-Barr virus activation. Planta Medica 61: $558-559$.

Inada A, Nakanishi T, Tokuda H, Nishino H and Sharma OP (1997) Anti-tumor promoting activities of lantadenes on mouse skin in tumors and mouse hepatic tumors. Planta Medica 63: 272-274.

Jain R, Singh M and Dezman DJ (1989) Qualitative and quantitative characterization of phenolic compounds from lantana (Lantana camara) leaves. Weed Science 37: 302-307.

Johns SR, Lamberton JA, Morton TC, Saures H and Willing RI (1983a) 22(S) -2-methylbutanoyloxy-3-oxoolean-12-en-28oicacid, a new constituent of Lantana camara. Australian Journal of Chemistry 36: 1895-1902.

Johns SR, Lamberton JA, Morton TC, Saures H and Willing R1 (1983b) Triterpenes of Lantana tiliaefolia. 24-hydroxy-3 oxours-12-en-28-oic acid, a newtriterpene. Australian Journal of Chemistry 36: 2537-2547.

Johnson JH and Jensen JM (1998) Hepatotoxicity and secondary photosensitization in a red kangaroo (Megaleia rufus) due to ingestion of Lantana camara. Journal of Zoo and Wild Medicine 29: 203-207.

Jusselme MD, Poly F, Miambi E, Mora P, Blouin M, Pando A, Rouland-Lefèvre C (2012) Effect of earthworms on plant Lantana camara $\mathrm{Pb}$-uptake and on bacterial communities in root-adhering soil. Science of the Total Environment 1: 200207.

Jusselme MD, Miambi E, Mora P, Diouf M, Rouland-Lefèvre C (2013) Increased lead availability and enzyme activities in root-adhering soil of Lantana camara during phytoextraction in the presence of earthworms. Science of the Total Environment 12: 101-109.

Jusselme MD, Poly F, Lebeau T, Rouland-lefèvre C, Miambi E (2015) Effects of earthworms on the fungal community and microbial activity in root-adhering soil of Lantana camara during phytoextraction of lead. Applied Soil Ecology 96: 151158 .

Kazmi I, Afzal M, Ali B, Zoheir A, Damanhouri, Ahmaol A, Anwar F (2013) Anxiolytic potential of ursolic acid derivativea stearoyl glucoside isolated from Lantana camara L. (verbanaceae). Asian Pacific Journal of Tropical Medicine 433-437.

Kellerman TS, Coetzer JAW (1985) Hepatogenous photosensitivity diseases in South Africa. Onderstepoort Journal of Veterinary Research 52: 157- 173.
Kessler RC, McGonagle KA, Zhao S, Nelson CB, Hughes M, Eshleman S, Kendler, KS (1994) Lifetime and 12-month prevalence of DSM-III-R psychiatric disorders in the United States: results from the National Comorbidity Survey. Archives of general psychiatry 51: 8-19.

Khan M, Srivastava SK, Syamasundar KV, Singh M, Naqvi AA (2002) Chemical composition of leaf and flower essential oil of Lantana camara from India. Flavor and Fragrance Journal $17: 75-77$.

Khan M, Srivastava SK, Jain N, Syamasundar KV, Yadav AK (2003) Chemical composition of fruit and stem essential oils of Lantana camara from northern India. Flavor and Fragrance Journal 18: 376-379.

Kong CH, Wang P, Zhang CX, Zhang MX, Hu F (2006) Herbicidal potential of allelochemicals from Lantana camara against Eichhornia crassipes and the alga Microcystis aeruginosa. Weed Research 46: 290-295. http://www.blackwell-synergy.com/doi/pdf/10.1046/99999999.99999.

Kumar S (2001) Management of Lantana in India: trend, prospects and need for integrated approach. In: Proceedings Workshop on Alien Weeds in Moist Tropical Zones: Banes and Benefits 91-106.

Kumar VP, Chauhan NS, Padh H, Rajani M (2006) Search for antibacterial and antifungal agents from selected Indian medicinal plants. Journal of Ethnopharmacology 107: 182188.

Kumar B, Smita K, Cumbal L, Debut A (2015) Lantana camara berry for the synthesis of silver nanoparticles. Asian Pacific Journal of Tropical Biomedicine 5: 192-195.

Kumarasamyraja D Jeganathan NS, Manavalan R (2012) Phytochemical investigation and antimicrobial activity of Acalypha indica. International Journal of Pharmaceutical Science 6: 313-316.

Lal M, Kalra DB (1960) Lantana poisoning in domesticated animals Lantana poisoning in domesticated animals. Indian veterinary journal 37: 263-269.

Liu J (1995) Pharmacology of oleanolic acid and ursolic acid. Journal of Ethnopharmacology 49: 57-68.

Liu J (2005) Oleanolic acid and ursolic acid: Research perspectives. Journal of Ethnopharmacology 100: 92-94.

Loganayaki N, Manian S (2010) In vitro antioxidant properties of indigenous underutilized fruits In vitro antioxidant properties of indigenous underutilized fruits. Food Science Biotechnology 19: 725-734. 
Lüi XR (2011) Quantitative risk analysis and prediction of potential distribution areas of common lantana (Lantana Camara) in China. Computational Ecology and Software 1: 60-65.

Macedo IT, Bevilaqua CM, de Oliveira LM, CamurçaVasconcelos AL, Morais SM, Machado LK, Ribeiro WL (2012) In vitro activity of Lantana camara, Alpinia zerumbet, Mentha villosa and Tagetes minuta decoctions on Haemonchus contortus eggs and larvae. Veterinary Parasitology 190: 504509.

Mahato SB, Sahu NP, Roy SK, Sharma OP (1994) Potential antitumor agents from Lantana camara: Structures of flavonoid- and phenylpropanoid glycosides. Tetrahedron 50: 9439-9446.

Manners AG, Walter GH (2009) Multiple host use by a sapsucking membracid: population consequences of nymphal development on primary and secondary host plant species. Arthropod Plant Interactions 3: 87-98.

Manners AG, Palmer WA, Dhileepan K, Hastwell GT, Walter GH (2010) Characterising insect plant host relationships facilitates understanding multiple host use. Arthropod-Plant Interactions $4: 7-17$.

Marsh EK (1978) The cultivation and management of commercial pine plantations in South Africa. Forestry and Environmental Conservation Branch Bulletin 56. Pretoria: Department of Forestry.

McSweeney CS, Pass MA (1982) Treatment of experimentallyinduced lantana poisoning in sheep. Journal of Applied Toxicology 2: 11-15.

McSweeney CS, Pass MA (1983) The mechanism of ruminal stasis in lantana poisoned sheep. Quarterly journal of experimental physiology 68: 301-313.

Mello FB, Jacobus D, Carvalho K, João RB, Mello (2005) Effects of Lantana camara (Verbenaceae) on general reproductive performance and teratology in rats. Toxicon 45: 459-466.

Misra LN, Dixit AK, Sharma RP (1997) High concentration of hepatoprotective oleanolic acid and its derivatives in Lantana camara roots. Planta Medica 63: 582.

Moffitt TE., Caspi A, Taylor A, Kokaua J, Milne BJ, Polanczyk G, Poulton R (2010) How common are common mental disorders? Evidence that lifetime prevalence rates are doubled by prospective versus retrospective ascertainment. Psychological medicine 40 : 899-909.

Mohamed NM, Makboul MA, Farag SF, Jain S, Jacob MR, Tekwani BL, Ross SA (2016) Triterpenes from the roots of
Lantana montevidensis with activity. Phytochemistry Letters 15: 30-36.

antiprotozoal

Moura MZD, Alves TMA, Soares GLG, dos Santos Isaias RM (2009) Intra-specific phenotypic variations in Lantana camara leaves affect host selection by the gall maker Aceria lantanae. Biochemical Systematics and Ecology 37: 541-548.

Muniappan R, Viraktamath CA (1993) Invasive alien weeds in the western Ghats. Current Science 64: 555-558.

Munir AA (1996) A revision taxonomic of Lantana camara L. and L.montevidensis Briq. (Verbenaceae) in Australia. Journal of Adelaide Botanic Gardens 17: 1-27

Munsif S, Khan MA, Ahmad M, Zafar M, Shah GM, Shaheen $N$ (2007) Leaf epidermal anatomy as an aid to the identification of genera Lantana, Verbena and Vitex of family Verbenaceae from Pakistan. Journal of Agriculture \& Social Sciences 3: 1813-2235.

Nagao T, Abe F, Kinjo J and Okabe H (2002) Antiproliferative Constituents in Plants 10. Flavones from the Leaves of Lantana montevidensis BRIQ and consideration of structureactivity relationship. Biological and Pharmaceutical Bulletin 25: 875-879.

Naik SR, Panda VS (2008) Hepatoprotective effect of Ginkgo select phytosome in rifampicin induced liver injury in rats: evidence of antioxidant activity. Fitoterapia 79: 439-445.

Naithani S, Pande PK (2009) Evaluation of Lantana camara Linn. stem for pulp and paper making. Indian Forester 135(8): 1081-1087

Nellis DW (1997) Poisonous plants and animals of Florida and the Caribbean. Pineapple Press Inc.

O’Neill MJ, Lewis JA, Noble HM, Holland S, Mansat C, Farthing JE, Foster G, Noble D, Lane SJ, Sidebottom PJ, Lynn SM, Hayes MV and Dix CJ (1998) Isolation of translactonecontaining triterpenes with thrombin inhibitory activities from the leaves of Lantana camara. Journal of Natural Products 61: $1328-1331$.

Obwolo MJ, Odiawo GO, and Goedegebuure SA (1990) Clinicopathological features of experimental low-dose Lantana camara poisoning in indigenous Zimbabwean goats. Zimbabwe Veterinary Journal 21: 1-7.

Obwolo MJ, Basudde CDK, Odiawo GO and Goedegebuure SA (1991) Clinicopathological features of experimental acute Lantana camara poisoning in indigenous Zimbabwean goats. Bulletin of Animal Health and Production Africa 39: 339-346.

Osunkoya OO, Perrett C (2011) Lantana camara L. (Verbenaceae) invasion effects on soil physicochemical properties. Biology and Fertility of Soils 47: 349-355. 
Oyouroua JN, Combrincka S, Regnier T, Marstonb A (2013) Purification, stability and antifungal activity of verbascoside from Lippia javanica and Lantana camara leaf extracts. Industrial Crops and Products 43: 820-826.

Palmer WA, Willson BW, Pullen KR (1996) The host range of Aconophora compressa Walker (Homoptera: Membracidae): a potential biological control agent for Lantana camara L. (Verbenaceae). Entomological Society of Washington (USA)

Palmer WA, Willson BW, Pullen KR (2000) Pullen, introduction, rearing, and host range of Aerenicopsis championibates (Coleoptera: Cerambycidae) for the Biological Control of Lantana camara L. in Australia. Biological Control 17: 227-233.

Parimoo HA, Sharma R (2014) Orally Induced Sub-Acute Toxicity of Lantadenes of Lantana camara in Guinea Pigs: A Haematological Study. Journal of Pathology 1(2): 12-15.

Parimoo HA, Sharma R, Patil RD, Patial V (2015) Sub-acute toxicity of lantadenes isolated from Lantana camara leaves in guinea pig animal model. Comparative Clinical Pathology 24: 1541-1552.

Pass MA, Seawright AA, Heath TJ (1976) Effect of ingestion of Lantana camara L. on bile formation in sheep. Biochemical Pharmacology 25: 2101-2102.

Pass MA, Findlay L, Pugh MW, Seawright AA (1979a) Toxicity of reduced lantadene A (22 $\beta$-angeloyloxyoleanolic acid) in the rat. Toxicology and Applied Pharmacology 51: 515-521.

Pass MA, Seawright AA, Lamberton JA, Heath TJ (1979b) Lantadene A toxicity in sheep: A model for cholestasis. Pathology 11: 89-94.

Pass MA, Mc Sweeney CS, Reynoldson JA (1981a) Absorption of the toxins of Lantana camara L. from the digestive system of sheep. Journal of Applied Toxicology 1: 38-42.

Pass MA, Poilitt S, Goosem MW, McSweeney CS (1985) The pathogenesis of lantana poisoning. Queensland Poisonous Plants Committee, Yeerongpilly Australia. Plant Toxicology pp.487-494.

Pass MA (1991) Poisoning of livestock by lantana plants. In: Handbook of Natural Toxins, Vol. 6, Toxicology of Plant and Fungal Compounds R. Keeler, and T. Anthony, eds., Marcel Dekker, Inc., New York. pp. 297-311.

Pereira JM, Barreto RW, Ellison CA, Maffia LA (2003) Corynespora cassiicola sp. lantanae: a potential bio control agent from Brazil for Lantana camara. Biological Control 26 : 21-31.
Pour BM, Sasidharan S (2011) In vivo toxicity study of Lantana camara. Asian Pacific journal of tropical biomedicine 1: 230-232.

Priyanka N, Shiju MV, Joshi PK (2013) A framework for management of Lantana camara in India. Proceedings of the International Academy of Ecology and Environmental Sciences $3:$ 306-323.

Rai PK (2012) An eco-sustainable green approach for heavy metals management: two case studies of developing industrial region. Environmental Monitoring and Assessment 184: 421448 .

Rai PK (2013) Plant invasion ecology: Impacts and Sustainable management. New York: Nova Science Publisher pp. 196.

Rai PK (2015a) Concept of plant invasion ecology as prime factor for biodiversity crisis: Introductory review. International Research Journal of Environmental Sciences 4: 85-90.

Rai PK (2015b) Invasion in different ecosystems, continents and global impacts on biodiversity: Multifaceted review on sustainable green approach. International Journal of Green and Herbal Chemistry 4: 461-473.

Rajashekar Y, Bakthavatsalam N, Shivanandappa T (2012a) Botanicals as grain protectants. Psyche: A Journal of Entomology. Article $\quad$ ID 646740. http://dx.doi.org/10.1155/2012/646740.

Rajashekar Y, Rao LJM, Shivanandappa T (2012b) Decaleside: a new class of natural insecticide targeting tarsal gustatory sites. Naturwissenschaften 99: 843-852.

Rajashekar Y, Ravindra KV, Bakthavatsalam N (2012c) Leaves of Lantana camara Linn. (Verbenaceae) as a potential insecticide for the management of three species of stored grain insect pests. Journal of Food Science and Technology 51: 3494-3499.

Rajashekar Y, Kumar HV, Kothapalli V Ravindrac, Nandagopal Bakthavatsalamc (2013) Isolation and characterization of biofumigant from leaves of Lantana camara for control of stored grain insect pests. Industrial Crops and Products 51: 224-228.

Rajesh KV, Suman KV (2006) Phytochemical and termiticidal study of Lantana camara var. aculeata leaves. Fitoterapia 77: 466-468

Rajwar, GS (1998) Changes in plant diversity and related issues for environmental management in the Garhwal Himalaya. In Headwaterswater resources and soil conservation: Proceedings of the fourth international conference on headwater control 335-343. 
Rimington C, Quin JI (1934) Studies on the photosensitization of animals in South Africa. VII. The nature of the photosensitizing agent in Geeldikkop. Onderstepoort Journal of Veterinary Science and Animal Industry 3:137- 157.

Rwangabo PC, Claeys M, Pieters L, Corthout J, Berghe DAV, Vlientinck AJ (1988) Umuhengerin, a new antimicrobially active flavonoid from Lantana trifolia. Journal of Natural Products 51: 966-968.

Samways MJ, Caldwell PM, Osborn R (1996) Ground living invertebrate assemblages in native planted and invasive vegetation in South Africa. Agriculture, Ecosystem and Environment 59: 19-32.

Sathish R, Vyawahare B, Natarajan K (2011) Antiulcerogenic activity of Lantana camara leaves on gastric and duodenal ulcers in experimental rats. Journal of Ethnopharmacology 134: 195-197.

Seawright AA (1963) Studies on experimental intoxication of sheep with Lantana camara. Australian Veterinary Journal 39: 340-344.

Seawright AA (1965) Toxicity for the guinea pig of an extract of Lantana camara. Journal of comparative Pathology 75: 215-221.

Seawright AA, Hrdlicka J (1977) The oral toxicity for sheep of triterpenoids isolated from Lantana camara. Australian Veterinary Journal 53:230-235.

Seawright AA, Allen JG (1972) Pathology of the liver and kidney in lantana poisoning of cattle. Australian Veterinary Journal 48: 323-331. DOI: 10.1111/j.17510813.1977.tb00195.x.

Seyoum A, Kabiru EW, Lwande W, Killeen GF, Hassanali A, Knols BG (2002) Repellency of live potted plants against Anopheles gambiae from human baits in semi-field experimental huts. American Journal of Tropical Medicine and Hygiene 67: 191-195.

Sharma OP, Makkar HPS, Pal RN, Negi SS (1979) LantanaThe hazardous ornamental shrub. Farmer Parliament14:18.

Sharma OP, Makkar HPS (1981) Lantana-the fore most livestock killer in Kangra district of Himachal Pradesh. Livestock Advise 6: 29-31.

Sharma OP (1984) Review of biochemical effects of Lantana camara toxicity. Veterinary Human Toxicology 26: 488-493.

Sharma OP, Dawra RK, Makkar HPS (1988a) Effect of polymorphic crystal forms of lantana toxins on icterogenic action in guinea pigs. Toxicology Letters 42: 29-37.
Sharma OP, Makkar HPS, Dawra RK (1988b) A review of the noxious plant Lantana camara. Toxicon 26: 975-987.

Sharma OP, Dawra RK, Pattabhi V (1991) Molecular structure, polymorphism and toxicity of lantadene A, the pentacyclic triterpenoid from the hepatotoxic plant Lantana camara. Journal of Biochemistry and Toxicology 6: 57-63.

Sharma OP, Vaid J, Pattabhi V, Bhutani KK (1992) Biological action of lantadene $\mathrm{C}$, a new hepatotoxicant from Lantana camara var. aculeala. Journal of Biochemical and Molecularr. Toxicology 7: 73-79.

Sharma OP, Sharma S, Pattabhi V, Mahato SB, Sharma PD (2007) A Review of the Hepatotoxic Plant Lantana camara. Critical Reviews in Toxicology 37: 313-352.

Shenoy KA, Somayaji SN, Bairy KL (2001) Hepatoprotective effect ofGinkgo biloba against $\mathrm{CCl}_{4}$-induced hepatic injury in rats. Indian Journal of Pharmacology 33: 260-266.

Sheppard, AW (2003) Prioritizing agents based on predicted efficacy: beyond the lottery approach. In: Spafford Jacob JH, Briese DT (Eds.), Improving the Selection, Testing and Evaluation of Weed Biological Control Agents. CRC for Australian Weed Management Technical series 7: 11-22.

Sheppard AW, Van Klinken RD, Heard TA (2005) scientific advances in the analysis of direct risks of weed biological control agents to nontarget plants. Biological Control 35: 215226.

Sheppard C, Alexander J, Billeter R (2012). The invasion of plant communities following extreme weather events under ambient and elevated temperature. Plant Ecology 213: 12891301.

Siddiqui BS, Raza SM, Begum S, Siddiqui S, Firdous S (1995) Pentacyclic triterpenoids from Lantana camara. Phytochemistry 38: 681-685.

Silva GN, Martins FR, Matheus ME, Leitão SG, Fernandes PD (2005) Investigation of anti-inflammatory and antinociceptive activities of Lantana trifolia. Journal of Ethnopharmacology $100: 254-259$

Singh M, Tamma RV, Nigg HN (1989) HPLC identification of allelopathic compounds from Lantana camara. Journal of Chemical Ecology 15: 81-89.

Singh SK, Tripathi VJ, Singh RH (1990) 3 $\beta$-24dihydroxyolean-12-en-28-oic acid, a pentacyclic triterpene acid from Lantana indica. Phytochemistry 29: 3360-3362.

Singh SK, Tripathi, VJ, Singh RH (1991) A new pentacyclic triterpene acid from Lantana indica. Journal of Natural Products 54: 755-758. 
Sousa EO, Costa JGM (2012) Genus Lantana: chemical aspects and biological activities. Revista Brasileira de Farmacognosia 22: 1115-1180.

Sousa FO, Miranda CMBA, Nobre CB, Boligon AA, Athayde ML, Costa JGM (2015) Phytochemical analysis and antioxidant activities of Lantana camara and Lantana montevidensis extracts Industrial Crops and Products 70: 7-15.

Srivastava SK, Khan M, Khanuja SPS (2005) Process for isolation of hepatoprotective agent "oleanolic acid" from Lantana camara. United State Patent. 6,884,908 (April 26).

Syah YM, Pennacchio M, Ghisalberti EL (1998) Cardioactive phenylethanoid glycosides from Lantana camara. Fitoterapia 69: 285-286.

Taviano MF, Miceli N, Monforte MT, Tzakou O, Galati EM (2007) Ursolic acid plays a role in Nepeta sibthorpii bentham CNS depressing effects. Phytotherapy Research 21: 382-385.

Totland O, Nyeko P, Bjerknes AL, Hegland SJ, Nielsen A (2005) Does forest gap size affects population size, plant size, reproductive success and pollinator visitation in Lantana camara, a tropical invasive shrub? Forest Ecology and Management 215: 329-338.

Trauner M, Meier PJ, Boyer JL (1998) Mechanisms of Disease: Molecular Pathogenesis of Cholestasis. The New England Journal of Medicine 339: 1217-1227.

Uppal RP, Paul BS (1978) Assessment of hepatic dysfunction in experimental lantana poisoning in sheep. Indian Veterinary Journal 55: 779- 802 .

Van Driesche RG, Carruthers RI, Center T, Hoddle MS, Hough-Goldstein J, Morin L, Smith L, Wagner DL, Blossey B, Brancatini V, Casagrande R, Causton CE, Coetzee JA, Cuda J, Ding J, Fowler SV, Frank JH, Fuester R, Goolsby J, Grodowitz M, Heard TA, Hill MP, Hoffmann JH, Huber J, Julien M, Kairo MTK, Kenis M, Mason P, Medal J, Messing R, Miller R, Moore A, Neuenschwander P, Newman R, Norambuena H, Palmer WA, Pemberton R, Perez Panduro A, Pratt PD, Rayamajhi M, Salom S, Sands D, Schooler S, Schwarzla"nder M, Sheppard A, Shaw R, Tipping PW, van Klinken RD (2010) Classical biological control for the protection of natural ecosystems. Biological Control doi:10.1016/j.biocontrol. 2010.03.003.

Venkatachalam T, Kumar VK, Selvi PK, Maske AO, Anbarasan V, Kumar PS (2011) Anti-diabetic activity of
Lantana camara Linn fruits in normal and streptozotocininduced diabetic rats. Journal of Pharmacy Research 4: 15502.

Verdeguer M, Blazquez MA, Boira H (2009) Phytotoxic effects of Lantana camara, Eucalyptus camaldulensis and Eriocephalus africanusessential oils in weeds of Mediterranean summer crops. Biochemical Systematics and Ecology 37: 362-369.

Verma DK, Singh, SK, Nath G, Tripathi V (1997). Antimicrobially active triterpenoids from lantana species. Indian Drugs 34: 390-392.

Wachter GA, Valcic S, Franzblau SG, Suarez E, Timmermann BN (2001) Antitubercular activity of triterpenoids from Lippia turbinate. Journal of Natural Products 64: 37-41.

Weir MP, Bethell SS, Cleasby A, Campbell CJ, Dennis RJ, Dix CJ, Finch H, Jhoti H, Mooney CJ, Patel S, Tang CM, Ward M, Wonacott AJ, Wharton CW (1998) Novel natural product 5,5-trans-lactone inhibitors of human alpha-thrombin: Mechanism of action and structural studies. Biochemistry 37: $6645-6657$.

Wright MG, Hoffmann MP, Kuhar TP, Gardner J, Pitcher SA (2005) Evaluating risks of biological control introductions: a probabilistic risk-assessment approach. Biological Control 35: $338-347$.

Yadav SB, Tripathi V (2003) A new triterpenoid from Lantana camara. Fitoterapia 74: 320-321.

Yapar K, Cavusoglu K, Oruc E, Yalcin E (2010) Protective role of Ginkgo biloba against hepatotoxicity and nephrotoxicity in uranium-treated mice. Journal of Medicinal Food 13: 179-188.

Zalucki MP, Day MD, Playford J (2007) Will biological control of Lantana camara ever succeed? Patterns, processes \& prospects. Biological Control 42: 251-261.

Zhang WJ, Chen B (2011) Environment patterns and influential factors of biological invasions: a worldwide survey. Proceedings of the International Academy of Ecology and Environmental Sciences 1: 1 .

Zoubiri S, Baaliouamer A (2012) GC and GC/MS analyses of the Algerian Lantana camara leaf essential oil: Effect against Sitophilus granarius adults. Journal of Saudi Chemical Society 16: 291-297. 